\title{
CU PRIVIRE LA MODALITĂȚILE DE REALIZARE INDIRECTĂ A ACTELOR DE VORBIRE ÎN LIMBA ROMÂNĂ
}

\author{
Tatiana SÎMBOTEANU \\ Institutul de Filologie Română „Bogdan Petriceicu-Hasdeu”, Chișinău
}

Rezumat. Chiar dacă există multiple mijloace de realizare indirectă a actelor de vorbire, scopul acestora rămâne a fi unul: cel de a spune mult mai mult decât a fost comunicat. Intrucât actele de vorbire sunt un fenomen lingvistic complex şi dinamic, la realizarea cărora participă mai mulţi factori, cum ar fi: contextul, locutorii cu nivelul lor de cunoştinţe comune, timpul şi locul situației discursive, există riscul confruntării cu dificultăți de sesizare a sensului autentic al unui astfel de act (enunţ). Pornind de la acest fapt, ne propunem să efectuăm o sistematizare a mijloacelor de realizare indirectă a actelor de vorbire şi o descriere a acestora pentru a facilita interpretarea univocă a mijloacelor de limbaj in diverse contexte.

Cuvinte-cheie: convenţionalizare, context situațional, act de vorbire indirect convențional, act de vorbire indirect nonconvențional, act de vorbire implicit.

Abstract. Though there are multiple means of indirect performance of speech acts, they have a common purpose to say much more than has been communicated. Whereas speech acts are a complex and dynamic linguistic phenomenon, which involves several factors such as context, speakers with their level of common knowledge, time and place of speech situation, there is a risk of facing difficulties in perceiving the true meaning of such an act (utterance). With that in mind, we propose to systematize the means of indirect performance of speech acts and to describe them in order to facilitate a univocal interpretation of the means of language in various contexts.

Keywords: conventionalisation, situational context, conventional indirect speech act, non-conventional indirect speech act, implicit speech act.

În orice situație concretă de comunicare, vorbitorul urmărește anumite scopuri comunicative: să transmită sau să solicite informații, să determine realizarea de către interlocutor a unei acțiuni sau se angajeze el însuși în realizarea unei acțiuni etc. Potrivit lui Austin, în procesul comunicării vorbitorii realizează acte de vorbire, definite prin relația care se stabilește, prin enunț, între cei doi interlocutori 
(Austin, 2005). În felul acesta, oricărui enunț i se asociază o anumită forță ilocuționară, reprezentând codificarea intenției comunicative a locutorului.

În structura enunțului, forța ilocuționară a actelor de vorbire este marcată prin mijloace de natură diferită: morfosintactică, lexicală sau suprasegmentală. În acelaşi timp, există situații în care această valoare nu dispune de mijloace proprii de exprimare, fiind sugerată de unele elemente implicate de contextul situațional al comunicării (GALR, II, p. 801). Dintre acestea cei mai importanți indicatori ai forței ilocuționare sunt structura morfosintactică a enunțului și verbele performative.

Pentru exprimarea forței ilocuționare a enunțului este importantă delimitarea celor trei tipuri de enunțuri, și anume, enunțurile asertive, interogative și imperative. În general, fiecare dintre structurile sintactice menționate este specializată pentru exprimarea unui anumit act de vorbire. Totuși, după cum observă cercetătorii, nu există o relație de 1:1 între actele de vorbire și structurile sintactice folosite pentru formularea lor. Se delimitează, pe de o parte, acte de vorbire formulate direct (sunt actele marcate prin structuri sintactice specializate) și, pe de altă parte, acte de vorbire formulate indirect, adică acte de vorbire marcate cu ajutorul unor structuri sintactice caracteristice altor acte. De exemplu, cererea este exprimată, de regulă, cu ajutorul unui enunț imperativ: Deschide, te rog, fereastra. Pentru realizarea acestui act de vorbire, în anumite situații, vorbitorii pot folosi și enunțuri interogative ( $A i$ vrea să deschizi fereastra?) sau chiar enunţiative (E prea cald aici.). După definiția clasică a lui J. Searle (1992, p. 72-75), un act de vorbire indirect se realizează prin intermediul mijloacelor specifice unui alt act de vorbire, acesta din urmă fiind determinat de structura morfosintactică a enunţului formulat.

Dacă interlocutorul, în baza diverselor tipuri de indicatori convenționali, recunoaşte o secvenţă discursivă drept act ilocuţionar de un anumit tip, acesta „intră în vigoare/ este valabil”, adică duce la asumarea unui ansamblu de drepturi şi îndatoriri pentru participanţii la dialog. Deci, realitatea empirică nu ne oferă pur şi simplu nişte enunţuri care indică prezenţa ideală a unui act ilocuţionar, ci mai degrabă ne propune nişte enunţuri care presupun existenţa / suprapunerea mai multor acte de limbaj. Complexitatea clasificării actelor de limbaj, în special a celor indirecte, ţine astfel de prelucrarea / interpretarea enunțurilor suport (Anquetil, 2010, p. 52).

Pentru actele de vorbire indirecte este caracteristic faptul că ele sunt realizate prin enunțuri folosite cu sens figurat, în care, sensul direct (primar) vine să motiveze sensul figurat (secundar), acesta de la urmă lipsind efectiv din discurs. De exemplu: De ce nu dormi la ora asta? (= Mergi imediat la culcare!). Este evident că în acest caz nu este vorba despre o întrebare, ci de un ordin, pentru a cărui realizare ar fi fost suficient să se spună „Pleacă chiar acum la culcare!”. Alte exemple: Nu aţi vrea să beţi un ceai? Ai o ţigară? Ce mai aştepţi? 
După cum putem observa, toate aceste enunțuri nu sunt nici pe departe întrebări. Ele exprimă invitația de a bea ceai, rugămintea de a fi servit cu o ţigară, indemnul de a pleca cât mai repede. În acelaşi timp, enunţurile: Ce zgomot e aici! Ce sete mi-e! nu au o valoare asertivă, ci imperativă, echivalând cu: Să plecăm de aici! şi „Dă-mi ceva de băut!' Desigur, în toate aceste cazuri puteau fi folosite structuri directe, care sunt mai laconice: Luați un ceai! Dă-mi o ţigară! Pleacă! Să mergem! Dă-mi să beau! Alegerea unor structuri mai complexe are legătură cu dorința locutorului de a atribui enunțului o anumită conotaţie (de politeţe, de emotivitate etc.), urmărind, astfel, ,îndulcirea” limbajului. Exprimarea indirectă a actelor de vorbire poate atenua unele efecte negative datorate exprimării directe a scopului ilocuţionar urmărit de locutor. Referindu-se la legătura strânsă dintre actele de limbaj şi relaţiile interpersonale, C. Kerbrat-Orecchioni le consideră rezervor de „relaţioneme”, de mare varietate şi capacitate (Kerbrat-Orecchioni, 2014, p. 68).

Spre deosebire de actele de vorbire directe care sunt descifrate pornind de la forma însăși a enunțului, actele de vorbire indirecte trebuie să fie reconstruite de ascultător prin inferență, pe baza unui calcul care face apel la mai multe tipuri de cunoștințe, lingvistice și extralingvistice. După cum menționează cercetătorii, în cazul utilizării actelor de vorbire directe vorbitorii rămân în sfera semanticii, iar în contextul folosirii actelor de vorbire indirecte semantica este dublată de anumiți factori de natură pragmatică.

Autorii care au studiat actele de vorbire indirecte vorbesc despre mai multe modalităţi de realizare a acestor entităţi. Vom încerca, în cele ce urmează, să descriem modalitățile de realizare indirectă a actelor de vorbire, folosindu-ne de exemple pentru a ilustra cum funcționează ele în situaţii concrete de comunicare.

1. Prima modalitate de realizare se întâlnește în cazul actelor de vorbire indirecte convenționale (numite uneori și acte indirecte idiomatizate). Prin convenţionalizare se înțelege, în acest caz, dotarea enunțului cu o semnificație care nu îi este specifică, ea fiind identificată uşor de ascultător fără implicarea unui anumit context. Pentru ilustrare vom aduce următoarele exemple:

Ai putea să închizi fereastra? (= Inchide fereastra!)

$N$-aţi putea să-mi spuneți cât e ora? (= Cât e ora?)

Ai putea să-mi dai un sfat? (= Dă-mi un sfat!)

Îmi dai o mână de ajutor? (= Ajută-mă!)

Ai o țigară? (= Dă-mi o țigară!)

La ce-ai mai venit? (= Nu trebuia să vii.)

Analiza exemplelor de mai sus demonstrează că semnificaţia unor astfel de construcții este deja înrădăcinată în limbă ca model stabil. Aceste enunțuri sunt produsul reproducerii structurilor standardizate în limbă, ele fiind utilizate în orice 
situație de comunicare cu același scop. Astfel, ele nu lasă loc altor interpretări, pentru că practic în orice context semnificația lor este înțeleasă univoc. Este vorba aici de o anumită stabilitate semantică, ceea ce permite ca interlocutorii, mai ales, dacă fac parte din acelaşi mediu socio-cultural, să poată uşor identifica intenția comunicativă a locutorului.

Important de reținut este faptul că ar fi greu să identificăm o trăsătură comună tuturor actelor de vorbire indirecte considerate a fi convenționale, în principal, din cauză că enunțurile prin care acestea sunt exprimate nu dispun de indici expliciți. Totuşi, după cum arată faptele de limbă analizate, pot fi relevate anumite trăsături semantice și formale specifice acestui tip de enunțuri. De exemplu, în cazul enunţurilor interogative folosite pentru exprimarea cererii, constatăm că majoritatea enunţurilor din această categorie menționează în mod explicit acțiunea solicitată interlocutorului. Pe lângă aceasta, unele dintre enunţurile de acest fel se pot referi la capacitatea sau la voința vorbitorului de a efectua acțiunea solicitată, precum și la motivele care ar putea determina realizarea acestei acțiuni. După structura lor aceste enunțuri sunt de tip interogativ având verbul predicat la persoana a II-a însoțit de modalizatorii a putea, a vrea sau a dori la indicativ ori la condițional, de exemplu, Poți deschide fereastra?; Vrei / ai vrea să deschizi fereastra? (= Deschide fereastra.). În cazul acestor enunţuri, vorbitorul îl întreabă direct pe interlocutorul său cu privire la capacitatea sau dorința lui de a închide fereastra, cerându-i indirect să facă acest lucru (Gauthier, 2001, p. 71). În felul acesta, deşi se chestionează voinţa sau posibilitatea interlocutorului de a realiza ceva, lui i se cere de fapt să realizeze acel lucru în legătură cu care este întrebat.

Foarte frecvent sunt folosite pentru exprimarea unui act de vorbire indirect enunţurile interogative atunci când vorbitorul îi solicită interlocutorului un anumit obiect. În acest caz enunţul interogativ exprimă o întrebare cu privire la posedarea de către interlocutor a obiectului respectiv, de exemplu, enunțul Ai un stilou? este echivalent cu Dă-mi, te rog, stiloul tău.

2. O a doua modalitate de realizare a actelor de vorbire indirecte o constituie cea care este specifică actelor de vorbire indirecte nonconvenționale. Spre deosebire de actele de vorbire indirecte convenţionale, acestea sunt realizate cu ajutorul unor enunțuri cărora li se poate atribui o forță ilocuționară secundară doar în raport cu anumite circumstanțe. De exemplu, un enunț asertiv de tipul Ușa este deschisă. ar putea fi echivalent, într-un context dat, fie cu o cerere, ajungând să exprime sensul: Închide ușa., fie cu un îndemn sau cu o permisiune: Poți / Puteți intra. În cazul unor astfel de acte de vorbire, locutorul folosește un procedeu derivațional datorită căruia semnificația marcată cu ajutorul unor mijloace formale ale se combină cu informaţia contextuală ceea ce face posibilă dezvoltarea actului de a cere sau de a permite ceva. 
În cazul în care locutorul intenţionează să solicite de la interlocutorul său un obiect, el poate folosi strategia complimentării, care reprezintă o afirmație indirectă a dorinței de a deține obiectul respectiv, de exemplu, Cartofii prăjiți arată tentant. ar putea fi folosit de locutor cu intenția de solicita să fie servit cu aceste bucate apetisante.

Un alt tip de enunţuri servind pentru exprimarea unui act de vorbire indirect nonconvențional poate fi ilustrat prin enunțul: Mâine vii cu părinţii la școală., adresat de către un profesor elevului său. Caracterizat printr-o valoare ilocuționară primară de afirmație, constatare, comunicare a unui fapt, enunțul respectiv este folosit în realitate pentru exprimarea unui ordin, a unei amenințări.

3. O altă modalitate de realizare a actelor de vorbire indirecte este reprezentată prin actele de vorbire indirecte implicite. Acesta este cazul enunțurilor care în situaţia concretă de comunicare îşi păstrează integral semnificaţia, însă în urma unui proces comunicativ-logic de analiză ele ajung să sugereze o altă semnificație. De exemplu:

\section{A.: - Ai vrea să mergem diseară la un film? B.: - Am mâine examen.}

În acest context, cel de al doilea enunț are rolul de a comunica un refuz implicit de a merge la film, chiar dacă nu avem o negație propriu-zisă. Locutorul nu își exprimă direct refuzul de a merge la un film, ci îi comunică interlocutorului său faptul că trebuie să se pregătească de examen. Informația dată este relevantă, reflectând cauza refuzului: Am mâine examen de care trebuie să mă pregătesc și de aceea nu pot să merg la cinema. Aşadar, din întregul şir explicit de evenimente vorbitorul enunță doar un singur element: motivul, cauza refuzului, restul subînțelegându-se.

La rândul său, ascultătorul fiind conștient că pregătirea pentru examen necesită timp și că poate fi un motiv să stai acasă în loc să mergi la film, concluzionează că locutorul i-a comunicat refuzul de a merge la film. Important este de observat că, intuitiv, expresia folosită nu este asociată direct cu sensul de refuz. Structura sintactică a enunțului dat indică cel mult că interlocutorul trebuie să se pregătească pentru un examen. Prin urmare, pentru a identifica refuzul este necesar un raționament inferenţial. Revenind la relaţia dintre actele de limbaj şi relaţiile interpersonale, în cazul actelor de vorbire indirecte implicite are loc trecerea responsabilității legate de sensul enunțat de la locutor la interlocutor, care este pus în situaţia de a se descurca singur cu interpretarea actului respectiv.

Prezentăm și un alt exemplu în care avem un caz de utilizare a actelor de vorbire indirecte implicite: - Eşti cu maşina? - Da, dar nu mă duc acasă. În acest caz, întregul lanț discursiv explicit ar fi următorul: Ce bine că eşti cu maşina, eu stau chiar lângă tine! Ai putea să mă duci şi pe mine acasă?) Și în acest caz constatăm că prin răspunsul său interlocutorul nu neagă direct, ci își exprimă motivul refuzului. 
În concluzie, vom menționa că actele de vorbire se realizează atât în baza principiilor formale ale limbajului, cât şi în baza unor principii comunicative inferențiale. Sesizarea semnificației autentice nu totdeauna depinde doar de structura morfosintactică a enunțului, ci și de contextul verbal sau situațional. Astfel, în funcţie de context, enunțurile folosite pentru realizarea actelor de vorbire pot fi înțelese fie în sens direct, fie în sens indirect. În cazul actelor de vorbire indirecte, valoarea ilocuționară primară este substituită printr-o valoare derivată, secundară. În aceste condiții, una dintre semnificații (sensul primitiv) este doar o motivare pentru sensul figurat, iar elementul discursiv utilizat indirect, este considerat ca element de realizare specială a sensului secundar, indirect (derivat).

După cum demonstrează faptele de limbă analizate, eterogenitatea tipurilor de enunţuri folosite în realizarea actelor de vorbire indirecte și diversitatea factorilor implicaţi în situaţiile concrete de comunicare fac ca orice explicaţie a fenomenelor de constituire a acestui tip de acte de vorbire bazată doar pe convenţie să fie neplauzibilă.

În ce privește modalitatea de actualizare a forței ilocuţionare în cazul enunțurilor folosite pentru realizarea unor acte de vorbire indirecte, distingem, pe de o parte, structuri sintactice care se caracterizează prin sens autonom şi independență faţă de uzul contextual în exprimarea acestei valori (actele de vorbire indirecte convenționale) și, pe de altă parte, structuri sintactice având legături strânse cu contextul (actele de vorbire indirecte nonconvenţionale și implicite). În felul acesta, forța ilocuționară a enunțurilor folosite pentru realizarea actelor de vorbire indirecte convenționale derivă din specificul construcţiei sintactice a enunţului şi din sensul cuvintelor care îl compun. Prin urmare, eficiența lor ilocuţionară rămâne în sfera lingvisticii. În același timp, forța ilocuționară a actelor de vorbire indirecte nonconvenționale și implicite poate fi determinată de interlocutor doar dacă ține cont de contextul discursiv. Aceste enunțuri nu pot fi luate izolat de condițiile sociale ale realizării lor.

\section{Referințe bibliografice}

1. ANQUETIL, Sophie. Peut-on classer les actes de langage indirects ? Étude d'un paradoxe sémantique, L'Information grammaticale $\mathrm{n}^{\circ} 127$, octobre 2010, p. 52-54, [online] Disponibil: https://www.persee.fr/doc/igram_0222-9838_2010_num_127_1_4123 [citat 23.10.2021].

2. AUSTIN, J. L. Cum să faci lucruri cu vorbe, trad. Sorana Corneanu, Piteşti: Paralela $45,2005,160 \mathrm{p}$. 
3. GARL, II = Gramatica limbii române. Vol. II: Enunţul. Bucureşti, Editura Academiei Române, 2005. 1036 p.

4. GAUTHIER, Gilles. L'indirection : Procédé d'expression et de persuasion en communication publique, Revista Canadiană de Lingvistică Aplicată, Vol. 4, Nr. 1-2, 2001, p. 6986, [online] Disponibil: https://journals.lib.unb.ca/index.php/CJAL/article/view/19832/21606 [citat 28.10.2021]

5. KERBRAT-ORECCHIONI, Catherine. Les actes de langage dans le discours. Theorie et fonctionnement, Ed. Armand Colin, Paris, 2014. 200 p.

6. SEARLE, John R. Sens et expression, étude de théorie des actes de langage, Paris, Les editions de Minuit, 1992, $243 \mathrm{p}$.

Notă: Articolul a fost realizat în cadrul proiectului de cercetare 20.80009.1606.01 Valorificarea științifică a patrimoniului lingvistic național în contextul integrării europene, Institutul de Filologie Română „B. P.-Hasdeu” al MEC. 